Revista de Psicología Vol. 39 (2), 2021 (e-ISSN 2223-3733)

\title{
The nationalist movements in Spain, today: a Catalonian and Basque comparison ${ }^{1}$
}

\author{
Catarina L. Carvalho ${ }^{2}$, Isabel R. Pinto ${ }^{3}$, José M. Marques ${ }^{4}$ \\ University of Porto, Portugal ${ }^{1,2,3}$
}

Pro-independence movements in the Basque Country and in Catalonia have old historical roots. Whereas in Catalonia the pro-independence social mobilization has recently gained energy, in the Basque Country it seems less prominent nowadays. We explore the psychosocial predictors associated with individuals' involvement in collective efforts towards independence in both these contexts. We distributed an online questionnaire among Basque $(n=132)$ and Catalonian $(n=152)$ independence supporters. Among the Basque independence supporters, pro-independence collective action tendencies were negatively predicted by perceived social status and identification with Spain, and positively predicted by patriotism and collective efficacy. Among the pro-independence Catalonians, only identification with Catalonia and collective efficacy beliefs predicted pro-independence collective action tendencies. These results are discussed considering historical, political, and socioeconomic factors.

Keywords: independence movements, nationalism, collective action

\section{Los movimientos nacionalistas en Espańa, hoy: una comparación catalana y vasca}

Los movimientos independentistas en País Vasco y Cataluña tienen viejas raíces históricas. En Cataluña la movilización pro-independencia ha ganado energía, pero en el País Vasco parece menos prominente. Exploramos los predictores psicosociales asociados con la participación en esfuerzos colectivos pro-independencia en ambos contextos. Distribuimos un

1 This work was supported by an individual doctoral grant awarded to the first author (PD/ BD/128211/2016), from the Fundação para a Ciência e Tecnologia, Portugal. The authors would like to thank to Darío Paéz, Magdalena Bobowik, Salvador Vargas-Salfate, and Marcela Gracia-Leiva for valuable contributions to the present work.

2 Ph.D student in Social Psychology at the University of Porto, Portugal. Postal address: R. Alfredo Allen, 4200-135 Porto, Portugal. E-mail: anacarvalho@fpce.up.pt https://orcid. org/0000-0002-4779-5328

3 Ph.D in Social Psychology, Professor at the University of Porto, Portugal. Postal address: R. Alfredo Allen, 4200-135 Porto, Portugal. E-mail: ipinto@fpce.up.pt https://orcid. org/0000-0001-5788-4140

4 Ph.D in Social Psychology, Full Professor at the University of Porto, Portugal. Postal address: R. Alfredo Allen, 4200-135 Porto, Portugal. E-mail: marques@fpce.up.pt https://orcid. org/0000-0003-3429-0774 
cuestionario en línea entre partidarios de la independencia de País Vasco $(N=132)$ y Cataluña $(N=152)$. Entre los vascos, las tendencias de acción colectiva pro-independencia fueron predichas negativamente por la percepción del estatus y la identificación con Espańa, y positivamente por el patriotismo y la eficacia colectiva; entre los catalanes, la acción colectiva se predijo solo por la identificación con Cataluña y creencias de eficacia colectiva. Estos resultados se discuten considerando factores históricos, políticos y socioeconómicos.

Palabras clave: movimientos por la independencia, nacionalismo, acción colectiva.

Os movimentos nacionalistas em Espanha atualmente: uma comparação Catalã e Basca Os movimentos independentistas no País Basco e Catalunha e têm raízes históricas antigas. $\mathrm{Na}$ Catalunha a mobilização social pró-independência ganhou energia recentemente, no País Basco ela parece ser menos proeminente. Neste estudo exploramos preditores psicossociais associados ao envolvimento em esforços coletivos pró-independência nestes dois contextos. Distribuímos um questionário "on-line" a apoiantes da independência da do País Basco $(N=132)$ e da Catalunha $(N=152)$. Entre os cataláes pró-independência, apenas a identificação com a Catalunha e crenças na eficácia coletiva predizem as tendências de ação coletiva; entre os bascos, as tendências de ação coletiva são preditas negativamente pelo estatuto social e pela identificação com Espanha, e positivamente pelo patriotismo e pela eficácia coletiva. Estes resultados são discutidos considerando fatores históricos, políticos e socioeconómicos. Palavras-chave: movimentos pela independência, nacionalismo, ação coletiva

\section{Les mouvements nationalistes en Espagne, aujourd'hui: une comparaison Cataloniane et Basque}

Les mouvements pro-indépendance basque et catalan ont des racines anciennes. En Catalogne, la mobilisation pro-indépendance s'est récemment intensifiée, alors qu'elle a diminué au Pays Basque. Nous explorons des prédicteurs psychosociaux de l'implication des individus dans des actions collectives visant l'indépendance, dans ces deux contextes. Nous avons distribué un questionnaire en-ligne à des partisans de l'indépendance basques $(N=132)$ et catalans $(N=152)$. Pour les répondants basques, le statut social et l'identification à l'Espagne prédisent négativement, tandis que le patriotisme et l'efficacité collective prédisent positivement, l'adhésion à l'action collective. Pour les catalans, l'identification à la Catalogne et les croyances à l'efficacité collective sont les seuls prédicteurs de l'adhésion à l'action pro-indépendance. Nous discutons les facteurs historiques, politiques et socio-culturels associés à ces résultats.

Mots-clés: mouvements d'indépendance, nationalisme, action collective 
Independence movements are not a new phenomenon. Quests for independence have occurred around the globe for centuries, such as, quests for political and economic independence, autonomy from a dominant state, or independence from a colonial power. Irrespectively of their main motivations, citizens supporting these movements share common characteristics along with a strong identification with their region or sub-state: They believe in the supremacy of their region as a nation, they feel that they are oppressed by an authoritarian and repressive central government or a foreign country, and they believe that they are entitled to decide about their political future, that is, that they have the right to self-determination.

Evidence suggests that regional identity is the main driving factor of support for independence, such that the more individuals identify with their region, the more they tend to favour its independence (Liñeira \& Cetrà, 2015). Regional identification is based, essentially, on a sense of shared history, culture, language, and perceived social cohesion (Dayton, 2015). Not surprisingly, this should be especially strengthened when the group is in competition, or when it endures inequality and grievances from a dominant outgroup (cf. Blake \& Mouton, 1961; LeVine \& Campbell, 1972; Rabbie \& Wilkens, 1971; Sherif, 1967). Basque and Catalonian citizens alike have a strong connection with their regions and a strong regional nationalism and patriotism, that are strongly related with support for independence (e.g., Johnston, 1995). Underlying these nationalisms are the beliefs that Basques and Catalonians are distinctive peoples within Spain, with their own languages, cultures and mores. This argument is the cornerstone for desired existence of their own independent states (Doyle, 2010). Although the preservation of the regional identity, language and culture usually emerge as the core argument for independence, other factors may be involved, such as, economic resentment, feelings 
of injustice (i.e., unfair treatment by the dominant group), and relative deprivation (e.g., Dowsett, 2017; Abrams \& Grant, 2011).

\section{The historical background of the Catalonian and the Basque quests for independence}

In Spain, the Basque and the Catalonia regions have traditionally struggled for independence from the Central Government of Madrid. These struggles date back to the Castilian and Aragonese feudal monarchies respectively, and flourished in the two regions by the nineteenth century with the development of the industrial era and the ensuing emergence of the modern metropolitan areas that differentiated them from the traditional rural Spain. They were revived following the Spanish Civil War (1936 - 1939) and in the ensuing Francoist dictatorship (1939 - 1975), during which Basque and Catalonian nationalists were persecuted, imprisoned, or executed (e.g., Beary, 2011; Johnston, 1995; Romão, 2013). Nowadays quests for independence in these regions seems to be based on different arguments and to spawn different levels of support and involvement on the part of their respective citizens. Specifically, whereas pro-independence social mobilization in Basque Country has stalled, in Catalonia it has increased (Barón, 2015). Indeed, although Catalonian and Basque independent movements have similar roots, they took different paths.

The Basque movement was marked by the emergence of the nationalist organisation ETA (Euskadi Ta Askatasuna, "Basque Homeland and Freedom”). ETA's rationale was to fight General Franco's brutal and oppressive dictatorship, and to struggle for the independence of the Basque Country by means of radical and violent strategies which killed hundreds of people (both Franco supporters or Government members and civilians). However, although initially ETA enjoyed the support of the population, fear, indignation and repulsion for its urban guerrilla actions lead many people to depart from this movement.

During the transition to democracy that followed Franco's demise, the Spanish state granted Statutes of Autonomy to seventeen different regions. However, some autonomous communities were granted more 
competences (i.e., autonomy) than others, as was the case of Basque Country (e.g., Gonzalez, 2016). Indeed, in an attempt to resolve the dispute with ETA and to stabilize the political situation in the region, the Spanish state granted the Basque Country larger fiscal independence (including allowing its own tax authority), more special benefits and a higher degree of autonomy (i.e., high level of self-governance), in comparison with the remaining regions (e.g., Barón, 2015; Gonzalez, 2016). This privileged autonomy of the Basque Country may have contributed to weaken quests for independence in the region (e.g., Dowsett, 2017). Nevertheless, ETA remained active until 2011. Due to ETA violent activity, the Basque independence movement was overshadowed, reduced to terrorist activities, and became less prominent than in the past (Sullivan, 2015). Indeed, ETA's violent activities caused great resistance and fatigue after years of violence, putting the independence debate in standby (Dowsett, 2017), and most of the Basque political groups became more focused on reconciliation processes than on contestation regarding the region's status with Madrid (Barón, 2015).

Unlike the Basque Country, Catalonia does not have a past of violence in its movements for independence, and, under the current Statuses of Autonomy, whereas the Basque Country exerts full control over its own tax revenue, Catalonia must transfer its tax revenues to the Central Government which then redistributes it by the remaining communities. Nevertheless, Catalonia holds the highest GDP of all Spanish regions (e.g., Cuadras-Morató, 2017; Schoen, 2018). The apparent imbalance between Catalonia GDP and its contribution to the poorer regions of Spain has fueled the debate about its independence, and the economic argument became the strongest point in favor of the independence of Catalonia (e.g., Schoen, 2018). The deterioration of Catalonian citizens' trust in the Spanish political system together with a wave of public outrage which fuelled the nationalist sentiment and the support for independence in Catalonia was intensified by the considerable setback for the welfare of the region brought about by the 2008 economic crisis, with the rising unemployment rates and the 
subsequent austerity policies, together with the revocation, in 2010 by the Spanish Constitutional Court, of the 2006 constitutional reform of the Catalonian Statute of Autonomy (which included a new tax deal and greater legislative independence from the central government), or the revocation by the Spanish Constitutional Court of the overturning of bullfighting that had been approved by the Catalonian parliament in 2010 (cf., Cuadras-Morató, 2017; Gonzalez, 2016; Liñeira \& Cetrà, 2015; Rico, \& Liñeira, 2014).

As a result of the above-mentioned events, September 11, 2012 (the Catalonia's national holiday, La Diada) was marked by, perhaps, the largest ever Catalonian nationalist demonstrations in contemporary times (Connolly, 2013). Since then, people have been using La Diada to express their discontent against the Central Government and to affirm their desire for independence. More recently, in October 1rst, 2017, a unilateral attempt to obtain self-determination through an independence referendum which had not been approved by the Central Government, was carried out by the government of Catalonia. In order to prevent the referendum and to control the streets of Catalonia, the Spanish government in Madrid mobilized a significant Civil Guard contingent to Catalonia. Some commentators claim that the Civil Guard used excessive force, recalling Franco's military dictatorship and intensifying Catalonian citizens' outrage and discontent. Moreover, the imprisonment of Catalonian elected politicians involved in the referendum, and their subsequent accusation in October 14, 2019, arose a series of popular protests in Barcelona and other cities. All these events have contributed to the feelings of frustration, resentment and injustice among pro-independence Catalonians regarding the Central Government's actions and increased their nationalist sentiment and support for the independence (e.g., Cuadras-Morató, 2017; Gonzalez, 2016; Liñeira \& Cetrà, 2015; Rico, \& Liñeira, 2014). 
The nationalist movements in Spain, today: a Catalonian and Basque comparison / Carvalho et al.

\section{Nationalist and patriotic sentiment underlying the independence movements}

Nationalism reflects individuals' belief in the superiority of their nation and that it should be dominant in the international scene (e.g., Mummendey, Klink, \& Brown, 2001; Osborne, Milojev, \& Sibley, 2017). Patriotism, on the other hand, reflects individuals' attachment to their nation, regardless of its international status, and involves feelings of belongingness, responsibility and pride (e.g., Mummendey, Klink, \& Brown, 2001; Osborne, Milojev, \& Sibley, 2017). Moreover, nationalism is usually associated with outgroup derogation, rejection and hostility, whereas patriotism involves a positive relation with the ingroup, regardless of which attitudes individuals may have towards the outgroup (Mummendey, Klink, \& Brown, 2001). Finally, nationalism is often related with the perception of an existing international competition over scarce resources (e.g., job, economic benefits), contributing to intergroup conflict (Jackson, 1993; Baughn, \& Yaprak, 1996). Thus, unfavorable economic conditions may favor the nationalist sentiment (Baughn, \& Yaprak, 1996). This seems to clearly apply to the Catalonian situation, which triggers a combination of nationalist and patriotic feelings and beef up the support for independence.

Moreover, evidence suggests that group identification, perceived injustice and believes in collective efficacy are key predictors of individuals' involvement in collective action (e.g., Tajfel, 1978; Van Zomeren, Postmes, \& Spears, 2008). These factors seem to be clearly present in the Basque and Catalonian settings as we described them above. In addition, the Catalonian people seem to have a stronger sense than the Basques of collective grievance and unfair treatment by the central state (e.g., Barón, 2015; Dowsett, 2017; Serrano, 2013). Catalonians also seem to believe that more autonomy (namely, holding their own tax authority, similar to the Basque Country) would economically benefit the region, in that it would increment the public budget and improve citizens' welfare (Serrano, 2013). In assuming that the wealth produced by Catalonia is retained by the Central Government and directed to 
the poorer regions of Spain, some Catalonian independentists claim that "Madrid steals from them" ("Madrid ens roba") and that a "Subsidized Spain lives at the expense of a productive Catalonia" ("L'Espanya subsidiada viu a costa de la Catalunya productive").

Nevertheless, along with a strong identification and feelings of injustice, to turn individuals' discontent into action it is also necessary that people believe that their collective efforts (e.g., marches, protests) can lead to the attainment of the desired outcome (e.g., Bandura, 1982). Therefore, for Catalonian and Basques' citizens to engage in social mobilization towards independence is crucial that they believe that through collective efforts they can influence the political system, bring about social change, contribute to social justice, and ultimately, achieve more autonomy and the independence for their nation (e.g., Bandura, 1982).

\section{The aim of our study}

Given the different pathways followed by the independence movements in the Basque Country and Catalonia and given the current political and socioeconomic context of each regions, the aim of the present study is to explore and to compare the psychosocial predictors and processes associated with citizens' involvement in proindependence movements in the two regions. We focus on individuals' identification with their region (Basque Country and Catalonia) and with Spain overall, on the perceived status of that region both in comparison with the remaining autonomous regions and with Madrid (the dominant region), beliefs about the supremacy of their region, agreement with independence, perceived Central government authoritarianism, nationalism and patriotism, and finally, beliefs in collective efficacy. Thus, we include all these predictors in our model to test their predictive effect on individuals' past participation in independence movements and motivation to get involved in future collective mobilizations (i.e., collective action tendencies). 
The nationalist movements in Spain, today: a Catalonian and Basque comparison / Carvalho et al.

\section{Method}

\section{Participants}

Participants are independence supporters from the Basque Country $(n=132)^{5}$ and Catalonia $(N=152)$.

Basque sample. Participants from the Basque sample are 34 female and 98 male native Basques or foreign citizens living in the Basque Country $^{6}$, aged 18 to 76 years-old $(M=36.93, S D=13.49)$, with completed basic education (3\%), secondary education (17\%) and higher education $(77 \%)^{73}$. The majority were employed $(70 \%)$ and student (19\%), and the remaining were retired (4\%), unemployed (3\%), and $5 \%$ indicated 'other situation'. Regarding participants' positioning on the left-right political spectrum, the average score on a 7-point Likertscale $(1=l e f t, 7=$ right $)$, was below the scale midpoint of $4(M=2.30$, $S D=1.63)$.

Catalonian sample. Participants from the Catalonia sample are 63 female and 89 male native Catalonians or foreign citizens living in Catalonia, aged between 18 to 85 years-old $(M=51.63, S D=12.23)$, with completed basic education (7\%), secondary education $(34 \%)$ and higher education $(59 \%)^{8}$; the majority were employed $(61 \%)$ and retired $(21 \%)$, and the remaining were unemployed $(11 \%)$, student $(2 \%)$, housewife $(2 \%)$, and $3 \%$ indicated 'other situation'. Regarding participants' positioning on the left-right political spectrum, the

5 The Basque sample was gathered from a larger study applied to general Basque population $(N=262)$. We selected only those participants who strongly supported Basques Country independence to allow a comparison with the Catalonian sample. This was necessary due to the difficulties encountered in accessing Basque pro-independence supporters (see Procedure section).

6 We asked participants to indicate their nationality through two options: Spanish or another nationality. When "other nationality" was selected, participants were asked to write their nationality in a text box. It is interesting to note that 56 participants from the Basque sample and 35 participants from the Catalonian sample indicated "other nationality" and wrote 'Basque' and 'Catalonian', respectively, as their nationality (in opposition with Spanish nationality). Additionally, we asked participants to indicate the community of birth (if native) and the community where they currently lived.

7 Four participants did not indicate education.

8 One participant did not indicate education. 
average score on a 7 -point Likert-scale $(1=$ left, $7=$ right $)$, was below the scale midpoint of $4(M=2.30, S D=1.41)$.

\section{Measures}

Participants responded to questions designed to assess their beliefs about the Basque Country / Catalonia social status, identification with Spain and Basque Country / Catalonia, independence agreement, perceived authoritarianism of Spanish Central Government, nationalism (regionalism), patriotism, collective efficacy and collective action tendencies.

Social status. Firstly, we asked participants to compare the Basque Country / Catalonia socioeconomic status with that of the other autonomous communities in general, on a 3 -point scale $(1=$ high, $2=$ average, $3=$ low). We recoded the scale so that higher values indicated higher beliefs in social status (i.e., 1 = low, 2 = average, 3 = high).

We also asked participants to compare the Basque Country / Catalonia socioeconomic status with that of Madrid $(1=$ lower position; $7=$ higher position).

Supremacy. Then we asked participants to compare the Basque Country / Catalonia with the Community of Madrid regarding, "prestige", and "power and influence", on 7-point scales ( 1 = lower position; 7 = higher position). We averaged these items to a Supremacy score, such that higher scores represent beliefs the supremacy of the Basque Country / Catalonia as compared to Madrid. The scale reliability was good for both the Basque $(\alpha=.63 ; M=5.05, S D=1.43)$ and the Catalonian $(\alpha=.68 ; M=4.80, S D=1.80)$ samples.

Identification. Participants answered to eleven questions designed to assess their identification with Spain and the Basque Country / Catalonia ( 1 = I fully disagree; 7 = I fully agree): (1) "In general, I identify a lot with Spain."; (2) "It is important for me to be Spanish."; (3) "In general, I am proud to be Spanish."; (4) "I prefer to be Spanish than any other nationality."; (5) "I have a strong connection with Spain."; (6) "I see myself more as a Basque (Catalonian) citizen than as a Spanish citizen."; (7) "In general, I identify a lot with the Basque 
Country (Catalonia )."; (8) "It is important for me to be Catalonian (Basque)."; (9) "In general, I am proud to be Basque (Catalonian)."; (10) "I prefer to be Basque (Catalonian) than any other Autonomous Community."; (11) "I have a strong connection with the Basque Country (Catalonia).”. We computed an Identification with Spain score (Basque sample: $\alpha=.77 ; M=1.40, S D=0.69$; Catalonian sample: $\alpha=$ $.75, M=1.38, S D=0.68)$ corresponding to the average of items 1 to 5; and an Identification with Basque Country / Catalonia score (Basque sample: $\alpha=.64, M=6.72, S D=0.47$; Catalonian sample: $\alpha=.93, M=$ $6.46, S D=1.16)$ corresponding to the average of items 6 to 11 .

Independence agreement. Participants agreement with the Basque Country / Catalonia independence were measured with a 6-item scale: (1) "Would you personally be in favor or against the independence of the Basque Country / Catalonia?" ( 1 = against, 7 = in favor); "Basque Country / Catalonia should be a nation... (2) because it has its own language."; (3) because of its history."; (4) because of its economy"; (5) because of its culture (mores and traditions)."; (6) for the conscience and desire of the people." $(1=$ I fully disagree; 7 = I fully agree). We averaged the scores of the items to an Independence agreement index, such that higher scores represent higher agreement with Basque Country / Catalonia independence. The scale reliability was good for both the Basque $(\alpha=.94 ; M=6.48, S D=0.40)$ and the Catalonian $(\alpha=.88 ; M$ $=6.49, S D=0.93)$ samples.

Perceived Government authoritarianism. As mentioned above, a strong identification with their sub-state, a strong belief in the supremacy of their region as a nation, and feelings that they are being oppressed by an authoritarian and repressive government or country, are common characteristics among independence supporters. We used a 5-item scale to assess participants' perception about central government authoritarianism ( 1 = I fully disagree; 7 = I fully agree $)$ :

9 Items 2 to 6 were based on the National and Regional Awareness: Catalonia study from the Spanish Sociological Research Center (Centro de Investigaciones Sociológicas, CIS), available at http://www.cis.es/cis/opencm/EN/1_encuestas/estudios/ver.jsp?\&cuestionario=1369\&est udio $=1218$ 
(1) "The Central Government of Madrid is an authoritarian government." and (2) "The Central Government resorts to repression and other forceful methods as a means to impose its will on the people."; (3) "The authoritarian actions of the Central Government against the Basque (Catalonian) people are a violation of civil rights and limit personal freedoms."; (4) "The Central Government resorts to repression to remain in power."; (5) "The Central Government tries to control and repress popular participation in the Basque Country (Catalonia)". We averaged these items' scores to a Government authoritarianism index, such that higher scores represent higher beliefs in Central Government authoritarianism. The scale reliability was acceptable for both the Basque $(\alpha=.87 ; M=6.14, S D=1.23)$ and the Catalonian $(\alpha=.58 ; M$ $=6.75, S D=0.63)$ samples.

Nationalism. To tap nationalism (regionalism), we used the Spanish version (Carvajal, 2010) of the Terhune (1964) nationalism scale, adapted for the Basque and Catalonian context. We selected 4 items from the original 6-item scale that best fit the context of independence movements ( 1 = I fully disagree; 7 = I fully agree): (1) "The Basque Country (Catalonia) should strive for power in the world."; (2) "The Basque Country (Catalonia) should try, with all its strength, to achieve the independence of all other Communities, both economically and politically."; (3) "The best way for The Basque Country (Catalonia) to progress is to maintain a strong identity and a sense of independent people."; (4) "The Basque Country (Catalonia) must seek to control its own destiny.". The Nationalism scale reliability was good for both the Basque $(\alpha=.71 ; M=6.27, S D=0.80)$ and Catalonian $(\alpha=.58 ; M=$ 6.24, $S D=0.90)$ samples.

Patriotism. Four items from the Kosterman and Feshbach (1989) patriotism scale were used to assess participants patriotism regarding the Basque Country and Catalonia ( $1=$ I fully disagree; $7=$ I fully agree): (1) "I feel a great pride in this land that is our Basque Country (Catalonia)."; (2) "I am emotionally attached to the Basque Country (Catalonia) and emotionally affected by its actions."; (3) "Although at times I may not agree with the Basque (Catalonian) government, my 
The nationalist movements in Spain, today: a Catalonian and Basque comparison / Carvalho et al.

commitment to Catalonia (Basque Country) always remains strong.", (4) "In general, I have little respect for the Basque (Catalonian) people." (reversed). The Patriotism scale reliability was good for both the Basque $(\alpha=.56 ; M=6.64, S D=0.56)$ and the Catalonian $(\alpha=.65 ; M=6.67$, $S D=0.70)$ samples.

Past participation (Basque sample). In the Basque sample we asked participants to indicate to what extent they had been involved, in the past (last 4 years), in each one of six collective activities related to the independence movements $(1=$ not at all involved; 7 = very much involved): (1) Human chain for the right of self-determination (June 8, 2014); (2) March for the independence of the Basque Country (December 6, 2015); (3) Sovereign consultations of 2016; (4) Sovereign consultations of 2017; (5) Sovereign consultations of 2018 ${ }^{106}$; (6) Human chain for the right of self-determination (June 10, 2018). We averaged the scores of these items to a Basques Past participation index $(\alpha=.93 ; M=5.01, S D=1.81)$.

Past participation (Catalonian sample). We asked participants to indicate to what extent they had been involved, in the past (the last 7 years), in a set of 9 collective activities that were related to the independence movements $(1$ = nothing involved; 7 = very involved $)$ : (1) La Diada "Catalunya, nou estat d'Europa"11 (2012); (2) La Diada "Via Catalana" (2013); (3) La Diada V - "Ara és L'hora, units per un pais nou" (2014); (4) La Diada "Via Lliure" (2015); (5) La Diada "A Punt, Endavant La República Catalana”(2016); (6) "La Diada del Si”(2017); (7) Independentist Referendum (October 1, 2017); (8) General Strike in Catalonia (October 3, 2017) ${ }^{12}$; (9) La Diada "Fem la República Cata-

10 The consultations were organized by the Gure Esku Dago ("It's in our hand") movement. The Gure Esku Dago “is a citizens' movement that fights for the right of self-determination of the Basque Country through a referendum (more information available on the website https://gureesku.eus/en/).

11 "La Diada" is the National Day of Catalonia celebrated on September 11th. This day has also been marked by pro-independence demonstrations.

12 The general strike was organized by Catalonian independentists, unions and cultural groups, two days after the Independentist Referendum. The strike represented a massive social mobilization in protest against the Central Government's actions and the police repression during the Independentist Referendum. 
lana" (2018). We averaged the scores of these items to a Catalans Past participation index (Cronbach's $\alpha=.95 ; M=5.88, S D=1.50$ ).

Collective efficacy. To assess participants' beliefs about collective efficacy, we used a 6-item scale (based on van Zomeren, M., Leach, C. W., \& Spears, R. 2010; van Zomeren, Postmes \& Spears, 2012) adapted to the Basque / Catalonian context ( 1 = I fully disagree; 7 = I fully agree): "I believe that if the Catalonians (Basques) act together... (1) they can change the current situation in Catalonia (Basque Country).”; (2) they can achieve the independence of Catalonia (Basque Country)."; (3) they can stop the actions of the Central Government against Catalonia (Basque Country)."; (4) they can defend their rights against the Central Government."; (5) they can successfully defend their interests."; (6) they can influence the decisions of the Central Government.". We averaged the scores of the items to a Collective efficacy index, such that higher scores represent stronger beliefs in the collective power of the Catalonian / Basque citizens to achieve their goals and change their current situation. The Collective efficacy scale reliability was good for both the Catalonian sample $(\alpha=.89 ; M=6.49, S D=0.90)$ and the Basque sample $(\alpha=.88 ; M=6.15, S D=0.96)$.

Collective action tendencies. Finally, we asked participants to indicate the extent to which they felt motivated to participate, in the future, in a set of 9 collective actions (based on Stürmer, \& Simon, 2004) in favor of the Basque Country / Catalonia independence ( $1=$ nothing motivated, 7 = very motivated): (1) Marches and public parades; (2) Protests and concentrations; (3) Information stands with flyer distribution; (4) Signing a petition; (5) Help to organize public campaigns; (6) Recruitment of new members; (7) Participation in special working groups; (8) Attend meetings; (9) Vote in a referendum for independence. The Collective action scale reliability was good for both the Catalonian sample $(\alpha=.90 ; M=5.78, S D=1.21)$ and the Basque sample $(\alpha=.90 ; M=5.61, S D=1.16)$. 
The nationalist movements in Spain, today: a Catalonian and Basque comparison / Carvalho et al.

\section{Procedure}

For the Catalonian sample, participants were contacted through Facebook groups to fill a survey about the independence movements in Catalonia. We only shared the invitation with the link to participate in the study in groups that clearly supported Catalonia independence (e.g., Per Catalunya; Catalunya Nou Estat; República de Catalunya! II*II Estat Català!; 3 Milions de Catalans per la independència de Catalunya). For the Basque sample, this procedure was not possible, since the number of Facebook groups supporting the Basque Country independence is small as compared to the case of Catalonia. Thus, the invitation with the link to participate in the study was shared through Facebook advertising ${ }^{13}$. Unfortunately, this method does not allow to restrict data collection to only those who support the Basque Country independence. To allow for comparison with the Catalonian sample, we then used a median-split procedure $(M d=5.83)$ in order to extract from the total sample of participants only those who strongly supported the independence of the Basque Country (Independence agreement).

In both samples, participation was completely voluntary and not monetarily compensated. After giving informed consent, participants provided their demographic information (e.g., age, sex, education, political orientation).

\section{Data analysis}

The data were analyzed using the Statistical Package for Social Sciences (SPSS) version 25.0 software. We conducted an independent-samples $t$ test in order to compare the means of the Basque and Catalonian samples for each measure and we estimated the productmoment correlations between collective action tendencies and our psychosocial predictors in order to evaluate the existence and strength of a linear relationship. We also conducted multiple linear regressions

13 Facebook ads allow to select participants based on participants location (Basque Country), gender and age (above 18 years old without age limit). 
analyses in order to observe the predictive effect of each predictor on collective action tendencies.

\section{Results}

Table 1 summarizes the descriptive statistics of all measures for each sample. In the Basque sample, the majority of participants indicated that the Basque Country holds a higher socioeconomic status (71\%) as compared to the other autonomous communities. The remaining participants indicated that the Basque Country holds an average (28\%) or lower (2\%) socioeconomic status compared to those communities. Conversely, the majority of Catalonian participants indicated that Catalonia holds an average socioeconomic status (43\%), with the remaining participants indicating that Catalonia holds a higher (30\%) or a lower $(26 \%)$ socioeconomic status in comparison with the other autonomous communities. Not surprisingly, considering the Basque Country Statutes of Autonomy, a comparison between the Basque and Catalonian samples (see Table 1) shows that the Basque participants more strongly believe in their region socioeconomic status (recalling the scale after recoded, $1=$ low, 2 = average, $3=$ high) than do the Catalonian participants (respectively, $M=2.69, S D=0.50$, and $M=2.04$, $S D=0.75), t(282)=8.46, p \leq .001$.

Participants also compared the Basque Country / Catalonia socioeconomic status with the Madrid status (in a 7-points scale, being $1=$ lower position and 7 = higher position). The Basque participants reported stronger beliefs in the socioeconomic superiority of their region as compared to Madrid, than did the Catalonian participants (respectively, $M$ $=4.98, S D=1.39$, and $M=3.07, S D=1.96), t(282)=9.34, p \leq .001$.

By comparing the supremacy scores, results showed no significant differences between the Basque sample $(M=5.05, S D=1.43)$ and the Catalonian $(M=4.80, S D=1.80), t(282)=1.28, p=.201$.

Basque and Catalonian participants alike reported a weak identification with Spain (respectively, $M=3.07, S D=1.96$, and $M=1.38$, $S D=1.96), t(282)=1.28, p=.201$. Basque participants showed higher 
identification with their region, than did Catalonian participants (respectively, $M=6.72, S D=0.47$, and $M=6.46, S D=1.16), t(28)=$ $2.41, p=.017$.

Basque and Catalonian participants showed strong agreement with the independence of their respective regions (respectively, $M=$ 6.48, $S D=0.40$, and $M=6.49, S D=0.93) t(282)=0.12, p=.909$. However, the Catalonian participants perceived the Spanish Central government as more authoritarian than did the Basque participants (respectively, $M=6.75, S D=0.63$, and $M=6.14, S D=1.23), t(282)$ $=5.36, p \leq .001$.

Both samples reported strong nationalist and patriotic positions (respectively, $M=6.27, S D=0.80$, and $M=6.64, S D=0.56$ for the Basque sample; $M=6.24, S D=0.90$, and $M=6.67, S D=0.70$ for the Catalonian sample), both $t(282)<1$.

Catalonian participants reported higher scores for past participation than did the Basque participants (respectively, $M=5.88, S D=$ 1.50 , and $M=5.01, S D=1.81), t(282)=4.43, p \leq .001$. Also, the Catalonian participants showed stronger beliefs in collective efficacy, than did the Basque participants (respectively, $M=6.49, S D=0.90$, and $M=6.15, S D=0.96), t(282)=3.08, p=.002$. Nevertheless, both the Basque and the Catalonian participants showed similar collective action tendencies scores (respectively, $M=5.61, S D=1.16$, and $M=$ $5.78, S D=1.21), t(282)=1.20, p=.230$. 


\section{Table 1}

Summary of Means and Standard Deviations by Sample

\begin{tabular}{|c|c|c|c|c|c|c|}
\hline \multirow[b]{2}{*}{ Variable } & \multicolumn{2}{|c|}{$\begin{array}{l}\text { Basque } \\
\text { Sample } \\
(N=132)\end{array}$} & \multicolumn{2}{|c|}{$\begin{array}{l}\text { Catalan } \\
\text { Sample } \\
(N=152)\end{array}$} & \multirow[b]{2}{*}{$t$} & \multirow[b]{2}{*}{$p$} \\
\hline & $M$ & $S D$ & M & $S D$ & & \\
\hline $\begin{array}{l}\text { Status in general } \\
(1=\text { low, } 3=\text { high })\end{array}$ & 2.69 & 0.50 & 2.04 & 0.75 & 8.46 & $\begin{array}{l}\leq \\
.001\end{array}$ \\
\hline $\begin{array}{l}\text { Status compared to Madrid } \\
(1=\text { inferior, } 7=\text { superior })\end{array}$ & 4.98 & 1.39 & 3.07 & 1.96 & 9.34 & $\begin{array}{l}\leq \\
.001\end{array}$ \\
\hline $\begin{array}{l}\text { Supremacy (compared to } \\
\text { Madrid; } 1=\text { inferior, } 7= \\
\text { superior) }\end{array}$ & 5.05 & 1.43 & 4.80 & 1.80 & 1.28 & .201 \\
\hline Identification with Spain & 1.40 & 0.69 & 1.38 & 0.68 & 0.25 & .806 \\
\hline $\begin{array}{l}\text { Identification with own } \\
\text { region }\end{array}$ & 6.72 & 0.47 & 6.46 & 1.16 & 2.41 & .017 \\
\hline Independence agreement & 6.48 & 0.40 & 6.49 & 0.93 & 0.12 & .909 \\
\hline $\begin{array}{l}\text { Perceived government } \\
\text { authoritarianism }\end{array}$ & 6.14 & 1.23 & 6.75 & 0.63 & 5.36 & $\begin{array}{l}\leq \\
.001\end{array}$ \\
\hline Nationalism & 6.27 & 0.80 & 6.24 & 0.90 & 0.30 & .768 \\
\hline Patriotism & 6.64 & 0.56 & 6.67 & 0.70 & 0.40 & .693 \\
\hline Past participation & 5.01 & 1.81 & 5.88 & 1.50 & 4.43 & $\begin{array}{l}\leq \\
.001\end{array}$ \\
\hline Collective efficacy & 6.15 & 0.96 & 6.49 & 0.90 & 3.08 & .002 \\
\hline Collective action & 5.61 & 1.16 & 5.78 & 1.21 & 1.20 & .230 \\
\hline
\end{tabular}

\section{Correlations between measures}

Table 2 displays the product-moment correlations between all measures in each sample. Regarding some of our demographic variables and political orientation, it seems noteworthy that, in the Catalan sample, age is positively associated with past participation $(r=.22, p=$ 
.008). In the Basque sample, age is also positively associated with past participation and collective action, but these relations are only marginally significant (respectively $r=.16, p=.073$, and $r=.15, p=.096$ ); education is negatively associated with past participation (marginally significant) and collective action (respectively $r=-.15, p=.094$, and $r$ $=-.18, p=.043$ ); political orientation is also negatively associated with past participation and with collective efficacy beliefs (marginally significant) (respectively $r=-.18, p=.040$, and $r=-.15, p=.084$ ).

It also seems noteworthy that beliefs about the Basque Country / Catalonia socioeconomic status compared to Madrid, are positively associated with collective action tendencies in the Catalonian sample $(r=.15, p=.074)$, but negatively associated in the Basque sample $(r=$ $-.17, p=.051)$. These correlations are significantly different $(z=2.68, p$ $=.004)$. By the same token, supremacy beliefs are positively associated with collective action $(r=.30, p \leq .001)$ in the Catalonian sample but not in the Basque sample $(r=-.03, p=.766)$. Furthermore, the association between regional identification and collective action is stronger among the Catalonians than among the Basques (respectively $r=.51, p$ $\leq .001$, and $r=.20, p=.020 ; z=2.99, p \leq .001)$. Similarly, the association between independence agreement and collective action is stronger among the Catalonians than among the Basque (respectively, $r=.42$, $p \leq .001$, and $r=.23, p=.008 ; z=1.78, p=.038$ ). Finally, identification with Spain is negatively associated with nationalism $(r=-.25, p=$ $.002)$ and patriotism $(r=-.20, p=.016)$ in the Catalonian sample but not in the Basque sample (respectively, $r=-.01, p=.951$, and $r=-.02$, $p=.784)$.

\section{Multiple linear regression analyses}

We used multiple linear regression analyses to test the predictive power of our predictors on citizens' mobilization towards independence (both past actions and future action intentions). We also included in our model age, education and political orientation. Firstly, we tested our regression model on participants' past participation (see Table 3). 


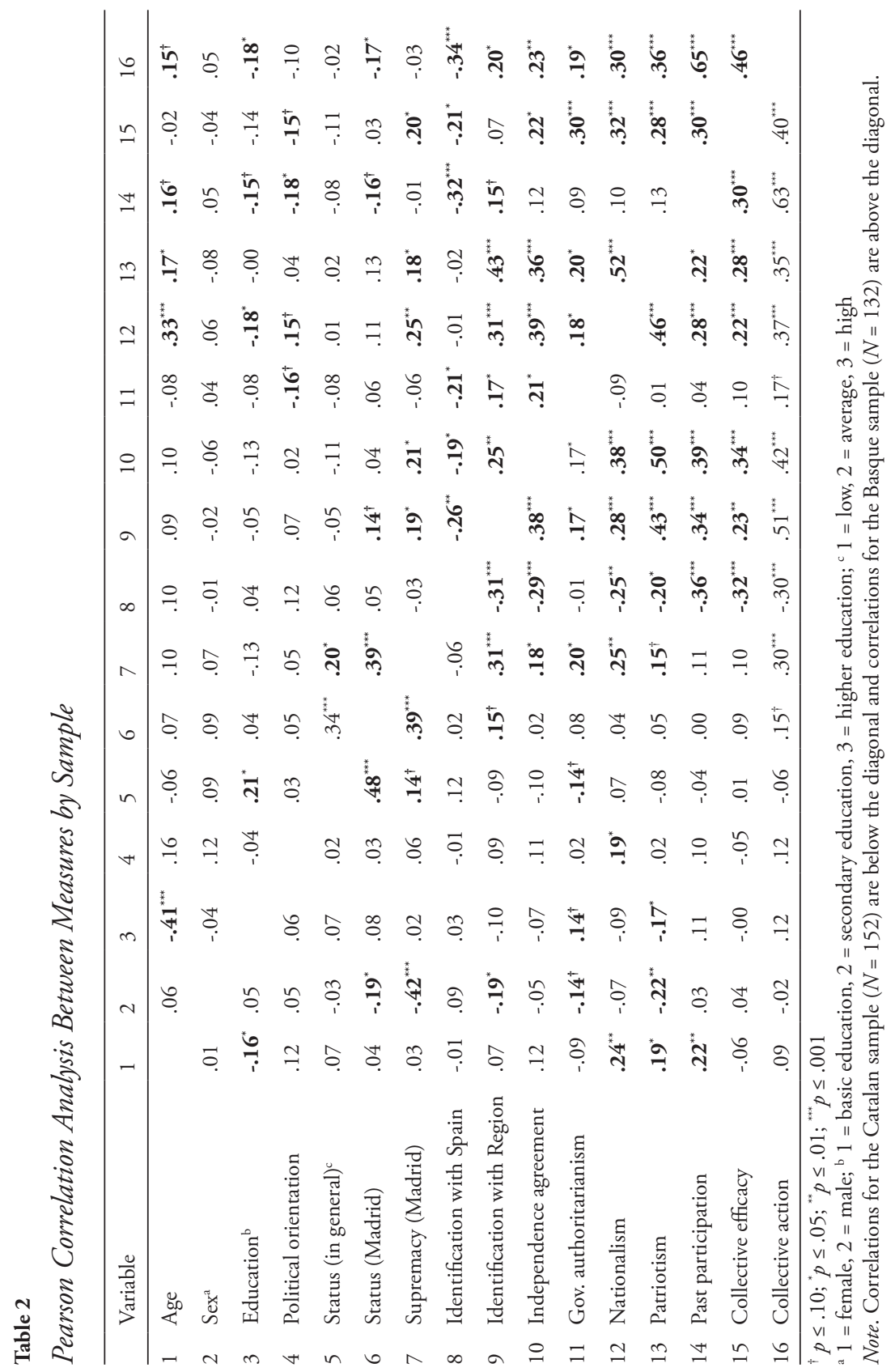


Regarding the Basque sample, regression results indicated that the model was a significant predictor, $F(13,114)=3.59, p \leq .001$, accounting for $21 \%$ of the variance in participants' past participation.

We observed that age $(\beta=.21, p=.030)$ and political orientation $(\beta=-.16, p=.060)$ were significant predictors of past participation.

More important to our research, we observed that only beliefs in Basque Country's status compared to Madrid ( $\beta=-.17, p=.058)$ and identification with Spain $(\beta=-.26, p=.003)$ negatively predicted past participation; patriotism $(\beta=.20, p=.056)$ and beliefs in collective efficacy $(\beta=.26, p=.007)$ were also significant predictors of past participation.

The model was also significant for the Catalonian sample, $F(13$, $137)=5.27, p \leq .001$, accounting for $27 \%$ of the variance in participants' past participation. Similarly, to the Basque sample, we also observe that age $(\beta=.20, p=.008)$ was a significant predictor of past participation, along with education $(\beta=.20, p=.007)$.

Contrary to what we found in the Basque sample, not only identification with Spain $(\beta=-.20, p=.011)$ negatively predicted past participation, but identification with Catalonia $(\beta=.18, p=.038)$ positively predicted past participation; agreement with independence $(\beta=.18, p=.047)$ was also a significant predictor, and beliefs in collective efficacy showed a marginally significant effect $(\beta=.14, p=.079)$ on past participation.

We tested our regression model on participants' collective action tendencies in favor of independence (see Table 3).

Regarding the Basque sample, the regression results indicated that the model was significant, accounting for $38 \%$ of the variance in participants' collective action tendencies $F(13,114)=7.08, p \leq .001$.

We observed that neither age, education nor political orientation were significant predictors of collective action tendencies. 


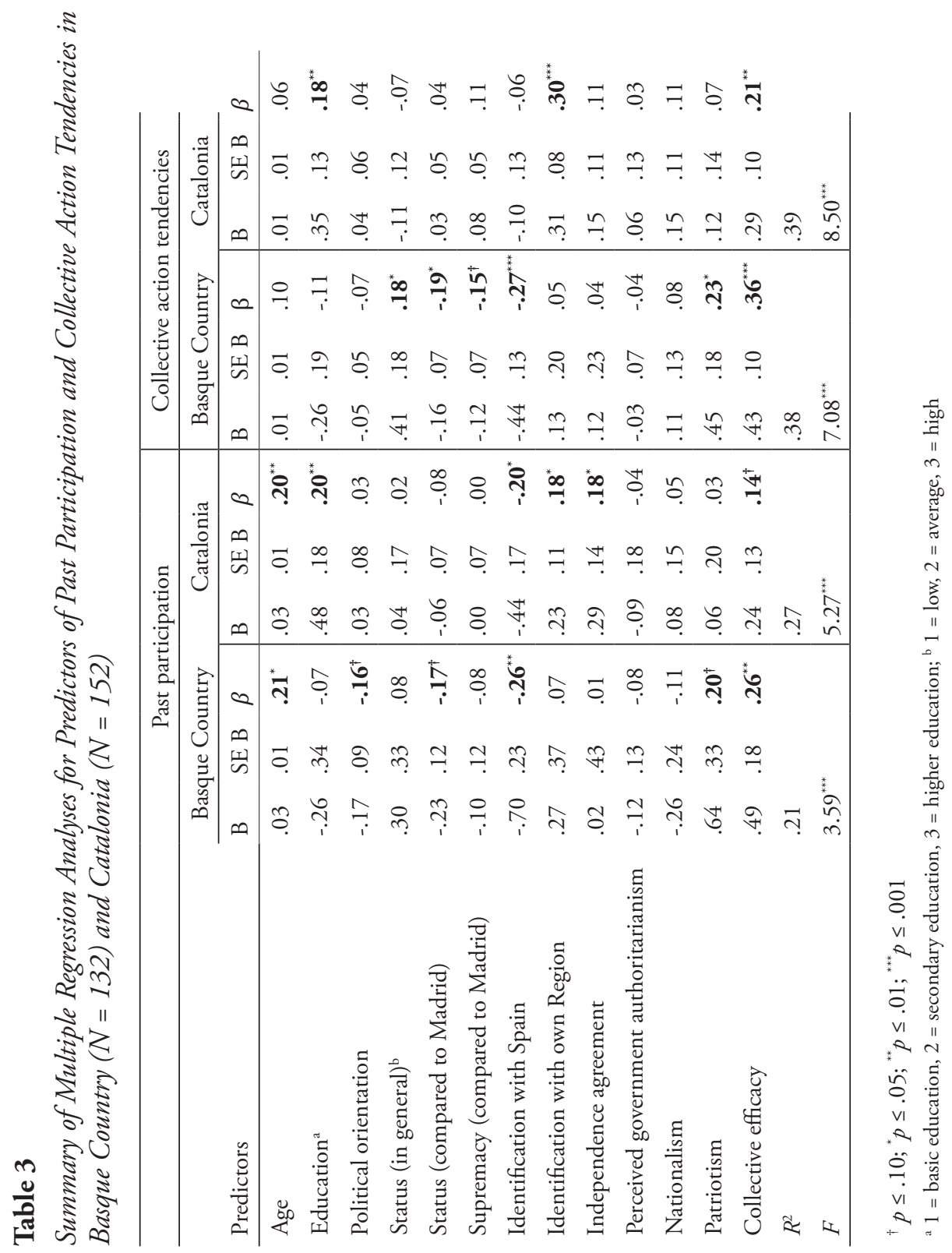


More important, perceived social status compared to the other autonomous communities positively predicted $(\beta=.18, p=.024)$; perceived social status compared to Madrid $(\beta=-.19, p=.019)$, and identification with Spain $(\beta=-.27, p \leq .001)$ negatively predicted; and Patriotism $(\beta=.23, p=.014)$ and beliefs in collective efficacy $(\beta=$ $.36, p \leq .001)$ positively predicted collective action tendencies. We also observed a marginally significant negative effect of supremacy beliefs ( $\beta$ $=-.15, p=.080)$ on collective action tendencies.

The model was also significant for the Catalonian sample, and explained $39 \%$ of the variance in participants' collective action tendencies, $F(13,137)=8.45, p \leq .001$.

As we observed with past participation, education $(\beta=.18, p=$ $.008)$ was also a significant predictor of collective action tendencies. We also observed that only identification with Catalonia $(\beta=.30, p \leq$. $001)$ and collective efficacy $(\beta=.21, p=.004)$ significantly predicted collective action tendencies.

Overall, the above results suggest that the Catalonian sample displays a pattern of psychosocial predictors that is more consistent with the processes described in the literature (e.g., Van Zomeren, Postmes, $\&$ Spears, 2008) than does the Basque sample.

\section{Discussion}

The aim of our study was to explore and to compare psychosocial predictors of support for independence in the Basque Country and Catalonia, of nationalist and patriotic sentiments, and, ultimately, of citizens' involvement in pro-independence movements. Based on previous literature, we focused on individuals' identification with their region (Basque Country and Catalonia) and with Spain, on the perceived social status of their region as compared either to the remaining regions and to the dominant region of Madrid, on their beliefs about the supremacy (prestige, power and influence) of their region as compared to Madrid, on perceived Central government authoritarianism, 
on their nationalism and patriotism, and finally, on their beliefs in collective efficacy.

A comparison between the means of the two samples on the above predictors suggests that the Basque participants hold stronger beliefs in their region's superior socioeconomic status in general and compared to Madrid, than do Catalonian participants. This is not surprizing given the fact that this is one of the richest regions of Spain, but especially because of the Statutes of Autonomy of the Basque Country. Nevertheless, participants of both samples reported strong beliefs in their region supremacy compared to Madrid, which is a common feeling among independence supporters, in association with nationalism, agreement with independence, and regional identification, together with a weak identification with Spain.

As expected, independence supporters also showed strong nationalist and patriotic sentiments. Catalonian participants also reported stronger perception of central government authoritarianism (e.g., "The Central Government of Madrid is an authoritarian government."), than did Basque participants. This is consistent with the persistent refusal, by the Spanish Central Government, to grant more autonomy to Catalonia and with several recent events in which the Central Government was perceived to attempt to oppress Catalonian independence supporters (e.g., Spanish Central Government's actions during the independence referendum of 2017, or the imprisonment and sentencing of politicians involved in the referendum). Finally, although the Basque participants reported lower involvement in past civil mobilization in favor of independence and weaker beliefs in collective efficacy than Catalonian participants, both showed similar motivation to get involved in future collective initiatives (if organized; in the Basque Country pro-independence initiatives appear to be less encouraged by political parties and pro-independence civil society groups, than in Catalonia).

The correlation coefficients also indicate that there are differences between both samples in the association between collective action tendencies and the possible predictors. Indeed, beliefs in the Catalonian 
socioeconomic status compared to Madrid and the supremacy of Catalonia is positively associated with collective action tendencies, which may be linked with a motivation to compete with the Madrid region over resources and power (cf. Baughn, \& Yaprak, 1996). Conversely, for the Basque participants, beliefs in the superior socioeconomic status of the Basque Country as compared to Madrid is negatively associated with collective action tendencies. Concomitantly, belief in the supremacy of the Basque Country is not related with collective action tendencies. Moreover, for Catalonian participants, nationalism is negatively associated with identification with Spain, possibly reflecting a relation between identification with Catalonia and Madrid derogation (cf. Mummendey, Klink, \& Brown, 2001). This pattern is not found in the Basque sample. In the whole, these results support the idea that the Catalonian sample undergoes a stronger conflict with the Spanish Central Government than Basque sample.

\section{Predicting citizen's mobilization towards independence}

The present results also suggest that Catalonian participants' past participation (e.g., La Diada, 2017 independentist referendum) is negatively predicted by their identification with Spain, and positively predicted by their identification with Catalonia and independence agreement. For the Basque sample, past participation is negatively predicted by identification with Spain and positively predicted by patriotism and collective efficacy. Thus, in both cases, (des)identification with Spain is a core predictor of past participation. For the Catalonians participants, it seems that viewing themselves as members of the regional group (i.e., the Catalonian people) is crucial to predict their past participation, whereas for the Basque participants, it is the attachment to, and pride about, their nation (i.e., patriotism) that predict past participation. For the Basque participants, it seems also essentially that they believed in the efficacy of their collective efforts towards independence. 
Regarding collective action tendencies, collective efficacy beliefs seem to be crucial for both Basque and Catalonian participants, to engage in future collective efforts towards independence. However, the remaining sociopsychological predictors differ between the two samples. Namely, whereas among Catalonian participants, identification with Catalonia (i.e., viewing themselves as Catalonian people) is the core predictor of collective action tendencies, among Basque participants collective action tendencies seem to be negatively predicted by beliefs in the Basque Country socioeconomic status superiority as compared to Madrid (Basque Country privilege) and identification with Spain; and positive predicted by beliefs in the Basque Country socioeconomic status superiority as compared to the other autonomous communities and patriotism. Thus, Basque participants' motivation to get involved in collective action seems to be better explain by the rejection of the Spanish state than by identification with the Basque Country, and the more these participants believed to be superior (supremacy) and that they hold a higher status compared to Madrid, the less they felt motivated to get involved in collective action towards independence. Again, the Basques' pride regarding their nation (patriotism) is essential to predict their collective action tendencies.

\section{Limitations of the present study}

In spite of the potential contribution of our results to a better understanding of individuals' involvement in pro-independence social mobilization, there are potential limitations that should be addressed in future research.

Due to the difficulties in accessing pro-independence supporters, and due to the data collection process used, it was not possible neither to use a representative sample of pro-independence supporters nor to obtain paired samples. Participants showed differences in terms of age, education and professional status, between samples. This fact calls for a cautious interpretation of the results. Nevertheless, our goal was not to compare the means of the two independent samples (the 
Basque Country and Catalonia samples), but to examine and compare the psychological processes underlying citizen's social mobilization towards independence in the Basque Country and Catalonia. Thus, we tested the predictive effect (regression model) of the sociopsychological factors discussed above. In addition, the aim of our study was also to emphasize the importance of considering multiple factors to better understand adhesion to independence movements. Indeed, we observed differences, between the Basque and Catalonian samples, in the predictive effects of each sociopsychological factors on collective action tendencies.

\section{References}

Abrams, D., \& Grant, P. R. (2012). Testing the social identity relative deprivation (SIRD) model of social change: The political rise of Scottish nationalism. British Journal of Social Psychology, 51(4), 674-689.

Bandura, A. (1982). Self-efficacy mechanism in human agency. American psychologist, 37(2), 122-147. https://doi. org/10.1037/0003-066X.37.2.122

Barón, A. (2015). Why Public Finance Matters: Evolution of Independence Movements in Catalonia and the Basque Country during the Twenty-First Century. SAIS Review of International Affairs, 35(2), 91-103.

Baughn, C. C., \& Yaprak, A. (1996). Economic nationalism: Conceptual and empirical development. Political Psychology, 759-778.

Beary, B. (2011). Separatist movements: A global reference. CQ Press, a Division of SAGE.

Blake, R. B. \& Mouton, J. S. (1961). Comprehension of own and of outgroup positions under intergroup competition. Journal of Conflict Resolution, 3, 304-310 
Cuadras-Morató, X. (2017, May). The Catalan economy: Crisis, recovery and policy challenges. In mBank-CASE Seminar Proceedings (No. 0145). CASE-Center for Social and Economic Research.

Dayton, R. (2015). Separatism, Globalization and the European Union. The Jean Monnet/Robert Schuman Paper Series, Miami, Florida, 1(15), 1-10.

Dowsett, S. (2017, October 9). The Basque Country: Spain's effective but expensive antidote to secession. Reuters. Available at https:// www.reuters.com/

Doyle, D. H. (Ed.). (2010). Secession as an international phenomenon: from America's Civil War to contemporary separatist movements. Georgia: University of Georgia Press.

Gonzalez, C. (2016). The Catalan National Identity and Catalonia's Bid for Independence. Conn. J. Int'l L., 32:1, 115-145.

Jackson, J. W. (1993). Realistic group conflict theory: A review and evaluation of the theoretical and empirical literature. The Psychological Record, 43, 395-414.

Johnston, H. (1995). The trajectory of nationalist movements: Catalan and Basque comparisons. JPMS: Journal of Political and Military Sociology, 23(2), 231-249.

Koomen, W., \& Van Der Pligt, J. (2015). The psychology of radicalization and terrorism. Routledge.

LeVine, R.A., \& Campbell, D. T. (1972). Ethnocentrism: Theories of conflict ethnic attitudes, and group behavior. New York, NY: Wiley.

Liñeira, R., \& Cetrà, D. (2015). The independence case in comparative perspective. The Political Quarterly, 86(2), 257-264.

Mummendey, A., Klink, A., \& Brown, R. (2001). Nationalism and patriotism: National identification and out-group rejection. British Journal of Social Psychology, 40(2), 159-172.

Osborne, D., Milojev, P., \& Sibley, C. G. (2017). Authoritarianism and national identity: Examining the longitudinal effects of 
SDO and RWA on nationalism and patriotism. Personality and Social Psychology Bulletin, 43(8), 1086-1099.

Rabbie, J. M. \& Wilkens, G. (1971). Intergroup competition and its effect on intergroup and intragroup relations. European Journal of Social Psychology, 1, 215-234. https://doi.org/10.1002/ ejsp.2420010205

Rico, G., \& Liñeira, R. (2014). Bringing secessionism into the mainstream: The 2012 regional election in Catalonia. South European Society and Politics, 19(2), 257-280.

Romão, F. V. (2013). O percurso das identidades nacionais espanhola, basca e catalã e dos respetivos nacionalismos. Oficina do CES, 399, 1-22.

Schoen, C. (2018, March 16). What's Next for Catalonia?. Harvard Political Review. Available at https://harvardpolitics.com/

Serrano, I. (2013). Just a matter of identity? Support for independence in Catalonia. Regional \& Federal Studies, 23(5), 523-545.

Sherif, M. (1967). Group conflict and co-operation: Their social psychology. London, UK: Routledge \& Kegan Paul

Sullivan, J. L. (2015). ETA and Basque Nationalism (RLE: Terrorism \& Insurgency): The Fight for Euskadi 1890-1986. Routledge.

Tajfel, H. (1978). Differentiation between social groups: Studies in the social psychology of intergroup relations. London, UK: Academic Press.

Van Zomeren, M., Postmes, T., \& Spears, R. (2008). Toward an integrative social identity model of collective action: A quantitative research synthesis of three socio-psychological perspectives. Psychological bulletin, 134(4), 504-535.

Recibido: 14 de febrero, 2020

Revisado: 5 de febrero, 2021

Aceptado: 6 de marzo, 2021 